\title{
Просветительская деятельность преподобного Стефана Пермского (1345-1396 гг.)
}

\author{
Владимир Борисович Помелов \\ Вятский государственный университет \\ Россия \\ vladimirpomelov@mail.ru
}

\author{
Василий Александрович Сахаров \\ Вятский государственный университет \\ Россия \\ ORCID: 0000-0002-0155-6188 \\ vas701@rambler.ru
}

\section{Людмила Геннадьевна Сахарова}

Вятский государственный университет Россия

ORCID: 0000-0002-6445-6416

slg75@rambler.ru

\begin{abstract}
В. Б. Помелов, В. А. Сахаров, Л. Г. Сахарова, The enlightenment activities of the Saint Stephen of Perm (1345-1396), Elpis, 21 2019: 51-57.

В. Б. Помелов, В. А. Сахаров, Л. Г. Сахарова, Działalność edukacyjna Świętego mnicha Stefana z Permu (1345-1396), Elpis, 21 2019: 51-57.

Abstract: The article gives the biographical facts and characteristics of the enlightenment activities of the outstanding Russian scholar and priest Saint Stephen of Perm. Attention is given also to St. Sergius of Radonezh and Epiphanius the Wise
\end{abstract}

Streszczenie: Artykuł zawiera dane biograficzne i opisuje działalność edukacyjną wybitnego rosyjskiego uczonego i księdza, Świętego mnicha Stefana z Permu. Zwraca się także uwagę na osobistości Świętego Sergiusza z Radoneża i Epifaniusza Mądrego.

\begin{abstract}
Аннотация: В статье приводятся биографические данные, и дается характеристика просветительской деятельности выдающегося русского ученого и священника, преподобного Стефана Пермского. Также уделяется внимание личностям Св. Сергия Радонежского и Епифания Премудрого.
\end{abstract}

Keywords: Saint Stephen of Perm, Vyatka krai, Old Permic script

Słowa kluczowe: Św.Stefan z Permu, Kraj Wiacki, Alfabet staropermski

Ключевые слова: преподобный Стефан Пермский, Вятский край, пермская азбука

Просветительская деятельность первых подвижников нашего родного Вятского края и соседних с ним территорий заслуживает внимательного изучения в силу того значения, каковое эта деятельность имела для духовно-нравственного развития жителей этого региона, и того влияния, которое она оказывала на дальнейшее развитие просвещения в крае и далеко за его пределами.

В данном материале предпринимается попытка охарактеризовать миссионерско-просветительскую деятельность выдающегося подвижника Северо-Запада России - Стефана Пермского и дать оценку его заслуг в деле распространения христианства и просвещения.

Выбор для подробного изучения просветительской деятельности именно этого подвижника просвещения объясняется тремя причинами.
Во-первых, Стефан Пермский - наиболее значимая историческая фигура, человек, внесший действительно крупный вклад в развитие культуры и просвещения в регионе.

Во-вторых, его просветительская роль представляется нам не в полной мере изученной, и наша работа, как мы полагаем, способна внести некоторый позитивный вклад в решение задачи исследования значения просветительской деятельности первых христианских подвижников Вятского и Коми-пермяцкого регионов.

В-третьих, сравнительно недавно, в 2014 г. в России на государственном уровне отмечался 700-летие со дня рождения преподобного Сергия Радонежского. Имена Сергия и Стефана связаны между собой писательскими усилиями Епифания Премудрого. Вот поче- 
му, воздавая должное Сергию Радонежскому, уместно вспомнить и о преподобном Стефане.

Миссионерско-просветительская деятельность Стефана Пермского осуществлялась в тот период, когда Русь освобождалась от ига иноземных захватчиков и уже начинало складываться централизованное государство из княжеств, объединявшихся вокруг Москвы.

Рост могущества Русского государства и установление экономических и политических связей с другими странами заложили основание для развития просвещения; тем самым была подготовлена почва для грядущих, в том числе просветительских, реформ Петра I. В этот период Вятка и Пермь были далекими окраинами русских земель. Просвещение здесь находилось в совершенно зачаточном состоянии. Оно получило толчок к своему развитию лишь благодаря усилиям первых просветителей-миссионеров, сочетавших в своей деятельности христианизацию местного населения и его обучение грамоте.

И первым по времени просветителем Вятской земли и «малых народов» Северо-Запада и Среднего Поволжья как раз и следует считать Степана Симеоновича Храпа (ок. 1345, г. Великий Устюг - 26. 04. 1396, г. Москва), более известного под именем Стефана Пермского.

Пермская земля с XII в. находилась в номинальной зависимости от Новгорода Великого, а с XIV в. населяющие ее коми-зыряне становятся данниками московского великого князя. В XVII в. Пермская земля - территория епископства Вятского и Великопермского (позднее и до настоящего времени - Вятского и Слободского).

Поэтому с полным основанием можно считать Стефана Пермского миссионером-просветителем не только коми-зырян, но и отчасти вятчан, по крайней мере тех из них, что проживали в северной части Вятской земли.

Стефан Пермский вошел в историю российского просвещения как создатель первой коми-зырянской азбуки, основоположник древнего коми литературного языка, писатель, переводчик, философ, художник, создатель первых коми школ, учитель и распространитель христианства в Перми Вычегодской, на территории епископства Вятского и Великопермского.

Отец Стефана Пермского Симеон был русским священником, причетником (клириком) соборной церкви Богородицы Великого Устюга Вологодского края, мать Мария - крестьянкой из коми-зырян. Первоначальное образование Стефан Пермский получил в семье.

В течение десяти-двенадцати лет он прослужил дьяком в Устюжском соборе, где «научился грамматической хитрости и книжной силе». В годы учебы в Ростовской монастырской школе Стефан принял монашество в монастыре Святого Григория Великого (Богослова), известном также под названием Затвор. Здесь, в Ростове Великом будущий просветитель постиг книжную грамотность, изучил греческий язык. Много времени он уделял переписыванию книг.
Именно здесь, в Ростове Великом во время совместной учебы он познакомился с будущим знаменитым православным писателем Епифанием Премудрым (? - между 1418 и 1422), написавшим вскоре после смерти Стефана Пермского его биографию («Житие»), а также биографию другого выдающегося просветителя преподобного Сергия Радонежского.

Исследователи называют Епифания обладателем исключительного литературного таланта и человеком передовых взглядов. Он был одним из выдающихся деятелей той культуры, которая определяется как культура Предвозрождения на Руси, как «время Андрея Рублева и Епифания Премудрого» [1].

Главная идея обоих указанных произведений Епифания Премудрого - создание образа совершенного учителя. При этом сам термин «учитель» понимался автором в высшем смысле этого слова, - как наставник в жизни.

В описании Епифания мы встречаем два различных типа Учителя. Сергий показан, прежде всего, как воспитатель и наставник, добрый пастырь, в то время как при характеристике Стефан биографом больший акцент делается на его научных заслугах.

Свою мудрость они постигают совершенно разными путями. Еще в детстве, как ни старался неспособный отрок Варфоломей (будущий Сергий) постигнуть «учение книжное», ничего у него не выходило. «Учитель с большим старанием учил Варфоломея, но отрок не слушал его и не мог научиться, не похож он был на товарищей, учащихся с ним. За это его часто бранили его родители, учитель же еще строже наказывал, а товарищи укоряли» [2, с. 279]. Но благодаря «Божественному откровению», отведав из рук святого старца кусок просфоры, вместе с ней Сергий получил и знания: «После ухода этого старца отрок внезапно всю грамоту постиг: изменился странным образом: какую книгу не раскроет, хорошо ее читает и понимает ее» [2, с. 279].

Однако, как известно, жизненная практика показывает, что для того, чтобы стать мудрым и образованным, необходим собственный труд человека, необходимо учение. В сборнике «Пчела» встречается, например, следующее высказывание: «Смешно есть, когда говорят, яко мудрость без учения бывает» [3, с. 233].

Путь труда в постижении мудрости в отличие от пути Сергия Епифаний изображает в «Житии Стефана Пермского». Стефан еще «детищем» был отдан учиться грамоте и через год знал ее настолько, что смог стать чтецом в соборной церкви. Мальчик постоянно упражнялся в славословии и грамматике, овладевая учением, как отмечает Епифаний, «естественною остротою ума своего».

В далеком Устюге он смог научиться «всей грамотичной хитрости и книжной силе». Для своего пострижения Стефан специально выбрал такой монастырь, где можно было достать много книг. Книги он читал «прилежно... учения ради, умедливая в учении, но до конца разумея, о чем говорит каждое слово в стихе» [2, c. 4-7]. 
Учился Стефан не только по книгам, но и в беседах с людьми, «... и если видит мужа мудрого и книжного и старца разумного и духовного, то бывает ему совопросником и собеседником, и с ним соводворяется, и ночует, и проводит утро, расспрашивая его с любопытством» $[4$, с. $4-7]$.

«Особенным» достижением Стефана было то, что выучив самостоятельно пермский язык, он «грамоту нову пермьску сложил и азбуки». Кроме того, он изучил греческий язык и «книги греческие изучил, и добре почитал их и всегда имел их у себя... при этом на греческом и пермском Стефан умел читать, писать и говорить» $[4$, с. 8$]$.

В рассказе об обучении Стефана отсутствует упоминание о каких-либо чудесах: он добивался в жизни всего сам «естественною остротою ума своего». Епифаний не противопоставлял двух просветителей друг другу.

Это были два разных типа учителей: «искушенный во «внешних науках», и все той же остротой разума постигающий глубины «слова Божьего», ученый и диспутант, рьяный миссионер, неутомимый просветитель, боец с головы до ног - Стефан Пермский, и озаренный откровенным знанием, тишайший «совопросник и собеседник» горнего мира, подвижник любви, поборник согласия, духовный собиратель родной земли, заступник ее - Сергий Радонежский» [5, с. 78].

При этом характером и судьбой сам Епифаний был, все таки, ближе к Стефану, - считает О. Е. Кошелева, - но своим истинным учителем он считал Сергия [3, с. 235], в чертах личности которого он особенно подчеркивал заботу о своих учениках.

Жития Стефана и Сергия, составленные Епифанием Премудрым, написаны стилем «плетения словес», который предполагает мало конкретных фактов и избыток риторики. Разумеется, Епифаний, лично знавший Стефана, мог бы включить в написанное им биографическое произведение гораздо больше фактологии, с тем, чтобы сделать для потомков фигуры как своего «однокашника», так и Сергия Радонежского, более осязаемыми, конкретными и значимыми.

Однако в своих литературных работах он был вынужден соблюдать предписанные свыше церковные каноны, не позволявшие автору «низводить» высокие канонические фигуры до уровня простых смертных; Стефан и Сергий должны были оставаться в сознании простых людей существами почти неземными.

Понятно, что любая конкретизация их образов, бытовые примеры и подробности их жизни сделали бы эти произведения более интересными и «очеловеченными»; дали бы больше материала для изучения последующим поколениям ученых, но, в то время, такой подход был заведомо невозможен и не мог быть одобрен церковью.

Помимо того, что в годы учебы Стефан, как уже отмечалось, усиленно занимался изучением славянского и греческого языков, у местного населения он выучился разговорному пермскому языку и задумал составить пермскую азбуку. «Житие...» свидетельствует о том, что даже в отдаленном Великом Устюге Стефан имел возможность изучать грамматику, греческий язык и знакомиться со значительным количеством книг.

Епифаний прославляет Стефана за то, что тот обращал зырян-пермяков в православие и перевел на зырянский язык книги «Священного писания». Для этой цели Стефан изобрел специальную азбуку, чем способствовал распространению просвещения среди этого народа. «Житие Стефана Пермского» впервые было издано Археографической комиссией под редакцией В. Г. Дружинина в г. Санкт-Петербурге в 1897 г.

В двадцать пять лет Стефан был посвящен в иеродиаконы. В качестве служения Стефан выбрал путь миссионерской деятельности среди коми-зырян, получив на это благословение епископа Коломенского Герасима. В 1378 г. московский митрополит Герасим направил Стефана в Пермский край проповедником. С переведенными им церковными книгами С. Пермский начал свою миссионерскую деятельность в 1379 г. «на Пыросе и на Виледе» (ныне район города Котласа Архангельской области).

Местом своего пребывания Стефан избрал устье реки Выми, где находилась кумирница коми-зырян, а возле нее священная береза, которой они поклонялись. Стефан сжег кумирницу (кумирню), срубил священную березу и в 1380 г. воздвиг на их месте православный храм - деревянную церковь Благовещения.

Стефан уничтожал капища и идолов пермских «идолаторов», крестил местное население, дискутировал с шаманами-кудесниками. Епифаний пишет, что, несмотря на столь активные действия, направленные на искоренение язычества и воцарение христианства, местные жители не тронули проповедника.

Так ли это было или нет, достоверно установить это в настоящее время уже невозможно. В то же время, известно, что очаги сопротивления нововведениям Стефана, несомненно, были, и эти ответные действия инициировались местными волхвами.

Активную проповедническую деятельность Стефан вел в зырянском селении Котлас, находящемся при впадении реки Вычегды в Северную Двину. В месте слияния Вычегды с рекой Вымью, на насыпном холме, напротив главной зырянской кумирни им была возведена церковь Благовещения Пресвятой Богородицы.

Согласно «Житию...», во время зырянского схода проповедь Стефана убедила всех местных жителей коми-зырян. Стефан построил еще две церкви на месте кумирни и на месте священного дерева зырян. Но против Стефана выступил волхв-кудесник Пам, бывший в то время уже древним старцем.

В «Житии...» приводятся слова волхвов, убеждавших соплеменников не слушать миссионера: «... От Москвы может ли что добро быти нам? Не оттуду ли нам тяжести быша и дани тяжкие и насильства и тивуни и доводщицы и приставницы?». Однако Паму возражали: «... Этот Стефан уничтожил наших богов, и они не могли ему вредить. Сняв пелены с главных ку- 
миров н отдал их, для поругания идолов, своему слуге Матвейку. И этот сделал из них подштанники и онучи и ногавицы и износил без всякого вреда, а был нашего же рода - пермин». [6, т. 2, с. 190-191].

Так Стефан развенчивал языческую веру своих соплеменников и утверждал христианскую веру, а вместе с ней и письменность, грамотность на пермской и вятской землях.

Стефан Пермский крестил коми-зырян, вводил богослужение на языке коми. Для этой цели в 1372 г. (по другим данным - около 1375 г.) Стефан на основе рунических знаков составил древне-пермскую азбуку, назвав ее по первым буквам азбуки «анбур» (или «абур»), и перевел на пермский язык несколько богослужебных книг.

В основу азбуки он положил греческий и славяно-русский алфавиты, используя, по мнению профессора В. И. Лыткина, «какие-то письмена, имевшие хождение между коми». Эти письмена (рунические знаки) применялись коми-зырянами при записи расчетов в меновой торговле с русскими.

Азбука Стефана Пермского имела оригинальную графику: она не повторяла имевшиеся алфавиты, а включала ранее не встречавшиеся начертания букв, некоторые из которых по написанию напоминают скорее арабские и римские цифры. Азбука состояла из 24 букв, «по числу букв греческой азбуки и по речи пермского языка», как отмечает Епифаний Премудрый.

Однако в дальнейшем получили распространение списки древнепермской азбуки, включавшие различное количество букв: от 24 в миллеровско-карамзинском списке до 28 в синодальном, мотоховском, ундольском списках. (Известны также яренский, номоканонский, усть-сысольский, устьсысольско-сводный, усть-сысольско-карамзинский, синодальный, усть-сысольско-калайдовичский списки).

Способ изобретения пермской азбуки Стефаном заимствован у Кирилла и Мефодия. Как в свое время основатели славянской письменности греческие монахи воспользовались готовыми болгарскими знаками, так и Стефан использовал для начертания некоторых элементов букв древне-пермской письменности некогда распространенные среди коми, а в его время уже выходившие из употребления родовые знаки, употреблявшиеся пермяками, в частности, в деревянных календарях (nacax). (У соседей коми - вотяков, то есть удмуртов, эти знаки назывались $n y c b l)$.

Палатализация согласных в азбуке С. Пермского особой графемой не обозначалась, а использовались надстрочные знаки, как это имеет место в некоторых современных языках (чешский, польский и др.). Епифаний писал, что Стефан «изучися сам языку пермьскому, и грамоту новую пермьскую сложи и азбуки незнаемы счини, по предложению пермьского языка, якоже есть требе... Се имена словом азбуки пермьские: ан, бур, гай, дой, э, жой, джой, зата, дзита, и, кокэ, лэй, мэно, во, пэй, рей, сий, тай, у, цю, черы, шой, ыры, вэр, о, я. Когда же се бысть или в кое вре- мя? И не давно, но яко мню о создания миру в лето 6883» [7, с. 9], то есть в 1375 г. по современному летоисчислению.

Впервые древне-пермская азбука была напечатана в 1817 г. Н. М. Карамзиным в «Истории государства Российского» (он взял ее из древней рукописи о жизни и делах Святого Стефана епископа Великопермского), а основные тексты были опубликованы в X1X в. исследователями П. Д. Шестаковым, П. И. Савваитовым, Г. С. Лыткиным. Окончательную расшифровку текстов и научное толкование их произвели В. И. Лыткин и А. С. Сидоров в ХХ в.

Стефан Пермский сделал переводы со старославянских церковных текстов на коми язык: части Библии, Часослов, Псалтирь, Осмогласник и др. Это был первый случай, когда канонические книги были переведены с русского языка на языки одного из других народов России.

Создание во второй половине XV в. алфавита для языка малочисленного, территориально окраинного народа - явление в истории России очень редкое и весьма значимое. Однако еще большее значение для духовного развития народа коми имела практическая просветительская деятельность Стефана, который с целью обращения местного населения в христианство перевел на древний язык коми молитвы и песнопения, организовал богослужение на языке новокрещеных, учил их грамоте, готовил духовенство из представителей местного населения.

Как создатель первой коми азбуки, первый переводчик церковной литературы не древнем языке коми и его «нормализатор» Стефан Пермский считается основоположником литературного языка коми.

В ходе своей подвижнической миссионерской деятельности выдающийся просветитель и его преемники организовали церковное богослужение и обучение на языке коми. Как утверждается в «Житии...», «...и научил их Стефан грамоте пермской, кою он до того наново сложил. И всем новокрещеным мужам, и юношам, и отрокам младым, и малым детям наказал учиться грамоте: читать часослов, осмигласник, псалмы Давидовы и все прочие книги.

Из обучающихся грамоте из тех, кто научился читать взятые книги, Стефан отбирал, одних поставляя в попы, других - в дьяконы, третьих - в падиаки (протодьяконы), чтецы, певцы, ноты перепевая, и переводя, и обучая их писать книги пермские. А те после этого учили друг друга грамоте и, книгу с книги переписывая, размножали их».

Профессор В. И. Лыткин утверждал, что «о создании большого количества книг на пермском языке, конечно, не приходится говорить: вероятно, Стефаном переведены были главнейшие песнопения, молитвы и некоторые места из Ветхого и Нового Завета» [8, с. 50]. В. И. Лыткиным было выявлено 12 текстов, написанных «стефаницей» и все они религиозного содержания. Но ни одного текста, составленного самим Стефаном, к сожалению, не сохранилось. 
Тем не менее, Стефан Пермский первым из просветителей фактически выполнил то, что спустя несколько столетий, в период европейской эпохи Просвещения, осуществили Мартин Лютер, Уильям Цвингли и Жан Кальвин, переведшие Библию на языки своих народов и, тем самым, давшие толчок к широкому развитию просвещения в Европе.

Стефан Пермский положил начало формированию литературного языка народа коми. Всех принявших крещение коми-зырян Стефан Пермский учил изобретенной им грамоте и чтению переведенных им текстов Священного Писания. Вокруг построенных им христианских церквей появилось селение Усть-Вымь, населенное коми-зырянами, принявшими крещение. Из их числа он рукоположил первых священников и диаконов.

В 1383 г. Стефан совершил поездку в Москву с целью просить о создании епископии. Вскоре Усть-Вымь становится центром Пермской епархии, а Стефан рукополагается первым пермским епископом. При его содействии здесь были построены несколько церквей (в поселках Усть-Выми и Вотче), в которых богослужение стало вестись на коми языке.

При церквах открывались школы, где обучались древнепермской грамоте дети и взрослые, «где сам (Стефан - В. П.) учил взрослых и детей грамоте, церковному пению и богослужебному порядку, часослову, осьмигласнику, псалтыри» [9, с. 34].

Миссионерская деятельность Стефана Пермского проходила в Коми-зырянском крае, но его азбука была известна и коми-пермякам. В 1390 г. он основал монастырь (пустынь) в селе Вотче по реке Сысоле, что в 60 километрах от современного города Сыктывкара (ранее поселок Усть-Сысолье).

Монастырь предназначался для монахов-пермян, проповедовавших христианскую веру среди местного населения. В Стефановском монастыре молитвы распевались на древнепермском языке до середины XVIII в. Все это происходило в непосредственной близости к прикамским удмуртам и вятчанам.

Удмурты - ближайшие родственники коми-пермяков по языку, и появление письменности у одного племени могло, как считают некоторые исследователи, возбудить своего рода некую зависть у другого племени, а также и желание овладеть грамотой.

Письменные источники конца XIV- начала XV вв. свидетельствуют о том, что для проповедей Стефан использовал любые возможности, в том числе поездки в Вятский край. Стефан осуществлял свою миссию, например, среди зюздинских «сырьян» (зырян) будущего Глазовского уезда (ныне территория Афанасьевского района Кировской области), а в поселении, предшествовавшем нынешнему городу Слободскому Кировской области, заложил часовню.

Во имя святителя Стефана вятчане позднее возводили храмы и часовни, а день его кончины 26 апреля с 1765 г. по 1920-е гг. отмечали особыми богослужениями и крестными ходами [10, с. 434].
Стефан Пермский перевел богослужение в местных храмах на язык коми, тем самым дав толчок к появлению целой группы священнослужителей-просветителей, которые занимались переписыванием книг и распространением грамотности. Распространению пермской азбуки Стефана благоприятствовало появление и довольно широкое распространение в России в $\mathrm{XIY} \mathrm{в.} \mathrm{нового} \mathrm{для} \mathrm{того} \mathrm{времени} \mathrm{материала} \mathrm{для} \mathrm{письма}$ - бумаги.

Епифаний Премудрый так писал о повседневных занятиях великого просветителя: «Петие им перепеваа и перелагаа и писати научая их пермския книги; и сам спомогаа им, переводящие с русских книг на пермские книги, и сиа предасть им. И так оттоле друг друга учаху грамоте, и от книг книгу переписующие, умножаху, испольняющие... Всех же крещеные своих... грамоте Пермской учаше... И попове его пермскым языком служаху обедню, заутреню же и вечерню, пермскою речию пояху... и чтецы чтение чтяху пермскою беседою...» [11, c. 135-136, 148-149].

В проповедях Стефан Пермский высоко оценивал значение образованности и грамотности. Он учил, что «надо учить детей грамоте пермстей... и млады дети загоде дя обучать грамоте» [11, с. 7]. Тех, кто обучился грамоте, следует, учил Стефан, в «попы поставлять».

Стефан Пермский наставлял учиться писать пермские книги, помогать друг другу и т. д. В своих молитвах Стефан Пермский давал светские и даже хозяйственные советы пермякам по ведению хозяйства, вплоть до того, как охотиться на белку и на медведя, как рубить дрова; отмечал, что всему этому надо учиться с детства.

Тем самым, можно считать его советы вполне педагогическими, а самого Стефана Пермского автором самых первых педагогических сочинений на Вятской и Пермской землях.

Стефан Пермский заложил принципы православной миссионерской деятельности. Его проповеди имели мирный характер. Он отказывался от помощи представителей великокняжеской администрации, чем вызывал доверие и уважение местного населения.

Стефан Пермский не только утверждал в Пермской и Вятской землях православное христианство, но и стремился улучшить жизнь народа коми: ходатайствовал перед великим князем об избавлении коми от насилия, тиунских продаж, добивался снижения дани, а в голодные годы организовывал закупку и раздачу хлеба.

Скончался Стефан в 1396 г. в г. Москве во время поездки в столицу по церковным делам. Похоронен в московском храме Спаса-на Бору, в Кремле. В «Житии...» приводится «Плач пермьскых людеи», сетующих о том, что Стефан «не на своем столе почил еси, добро же бы было нам, аще бы рака (гроб) мощии твоих была у нас, в нашей стране, в твоеи епископьи, нежели в Москве не в своем пределе...» [11, с.157].

Распространение христианства в Пермской земле не всегда было мирным. Вооруженное сопротивление этому процессу оказывали вогулы - предки народа ман- 
си. Они нападали на крещеных коми-зырян и русских миссионеров, а в 1455 г. убили пермского епископа Питирима - непосредственного преемника Стефана. Сопротивление вогулов было сломлено лишь с помощью московского военного отряда, прибывшего с новым епископом Ионой. В 1463 г. Иона крестил коми-пермяков, живших по рекам Каме, Вишере и Чусовой.

Дело просвещения Пермской и Вятской земель продолжалось и при преемниках Стефана - епископах Питириме, Ионе, Герасиме, Филофее. Однако позднее возникли трудности в связи с тем, что в 1503 г. центр епархии был перемещен из Усть-Выми, где жили Стефан Пермский и его сторонники и ученики, в Вологду и сама епархия получает название Вологодской и Великопермской.

Затем в Хлынове (Вятке) возникает Вятская и Великопермская епархия. В связи с этим церковное богослужение стало вестись на церковно-славянском языке и древний язык коми стал постепенно забываться.

Период распространения литературы на древнем языке коми Иван Алексеевич Куратов, основоположник новой коми литературы, назвал «оазисом в пустыне зырянской (коми) истории».

Письменность, созданная Стефаном Пермским, получила распространение по всей территории Коми-зырянского и Коми-пермяцкого краев, а также на территории Вятской земли, в той ее части, которая была населена народом коми.

До нашего времени памятники пермской письменности дошли в виде надписей на иконах и в виде отдельных, случайно сохранившихся записей на полях книг и т.п., в общей сложности 236 слов связного текста. Хотя книги на древнем языке коми утеряны, но сама азбука дошла до наших дней. Стефановской азбукой пользовались вплоть до XIX в. И. А. Куратов свои первые работы писал, используя азбуку древнего языка коми.

Одним из значительных памятников русской и коми культуры является «Поучение епископа Стефана против стригольников», с которым епископ выступил в Новгороде против еретиков (стригольников).

В этой проповеди Стефан Пермский дал отповедь стригольникам, которые, по его словам, оклеветали «весь вселенский събор, патриархов, и митрополитов, и епископов, и игуменов, и попов, и весь чин священничьский, яко не по достоянию поставляеми».

Стефановская азбука просуществовала в общей сложности три века и стала выдающимся явлением в истории культуры народов Поволжья и Прикамья. Но азбука Стефана Пермского, к сожалению, не пустила глубоких корней в народе, не стала его письменностью. Древнеписьменный пермский (коми) язык был только языком церкви, недоступным простому народу. Письменность, которой не пользовался народ для выражения своих взглядов, чувств и убеждений с целью повседневного и всестороннего общения, обречена на вымирание, справедливо отмечает В. В. Прокошев $[1$, c. 8$]$.
В. В. Прокошев выделяет несколько серьезных причин, побудивших коми-пермяков к непринятию азбуки Стефана Пермского. Прежде всего, это колонизация и насильственная христианизация, которые насаждались в Пермском крае «огнем и мечом». После проповедей Стефана Пермского, угрожавшего божьей карой язычникам, «кудесник» Пам, уговорив часть пермяков не отказываться от языческих обычаев и не принимать христианской веры, увел их на Обь. Впоследствии другой массовый уход был при крещении местного населения епископом Ионой в конце XV в., третий - в результате проповеди Трифона Вятского, четвертый - как протест против крепостного гнета Строгановых.

Еще одной важной причиной, воспрепятствовавшей принятию коми-пермяками азбуки Стефана, был низкий уровень их социально-экономического развития; им было просто не до грамоты. Как видим, все эти причины носили, скорее, социальный характер, и не были связаны с достоинствами или недостатками самой азбуки.

Кроме того, распространению грамотности на родном языке среди коми-пермяцкого населения фактически препятствовала русская православная церковь, распространявшая церковную литературу на церковно-славянском языке.

Опыт создания грамоты для «малого» народа был фактически обречен на неудачу, поскольку пермяки не были готовы воспринять письменность, да и сама по себе идея «инородческой» письменности еще и значительно позже встречала неодобрение части, причем именно влиятельной части, российского общества.

Стефан Пермский был первым и наиболее выдающимся Пермским епископом. Он неизменно выступал на стороне своего друга, великого князя и государственного деятеля Дмитрия Донского и проявил себя как сторонник укрепления централизованной государственной власти и авторитета православной церкви. Стефан Пермский указывал, что «не для того дела дал Христос Евангелие в мир, чтобы, почитая его, смотрели того слова, чем бы кого укорити».

Он проявил себя и как политик. Благодаря своему таланту оратора он убедил новгородское вече воздействовать на великоустюгских ушкуйников, ранее нападавших на Коми край. В 1387 г. он добился того, что «пермяне», постигнутые неурожаем, получили хлеб из Вологды и Устюга. В 1391 г. он убедил вятчан прекратить свои набеги на Пермские земли.

Исследователи истории отечественной культуры придают большое значение просветительской деятельности Стефана Пермского и ставят его в один ряд с выдающимися деятелями России.

Так, русский философ Г. П. Федотов, называя Стефана Пермского одним из образованнейших людей своего времени, отмечал, что он «был одним из немногих людей Древней Руси, которые могли читать и говорить по-гречески. 
Вместе с пермским это давало ему знание трех зыков - явление, может быть, не столь редкое в древнем Киеве, но уже совершенно исключительное явление на Московском Севере... Стефан-эллинист - был редким явлением на Руси. Стефан - создатель зырянской письменности - явление совершенно исключительное. Он не пожелал соединить дело крещения язычников с их обрусением. Не пожелал и идти к ним со славянской литургией, разъясняемой проповедью на народном языке» [12, т. 2, с. 288-289].

Стефан Пермский был и художником-иконописцем. Одна из его известных икон - «Зырянская троица» (хранится в г. Вологде) считается замечательным произведением иконописи XIV в., предварявшим рублевскую «Троицу», благодаря своему глубокому философско-патриотическому содержанию.

По мнению исследователей, художник выразил в иконе такие общественно значимые идеи как необходимость согласия и единства, готовность к самопожертвованию [13].

Миссионерско-просветительская деятельность Стефана Пермского была в известной степени продолжена Трифоном Вятским, который выступил фактически основателем православного просветительства «на Вятке».

\section{Библиография}

1. Prokošev, V. V. (red.). (1976). Iz istorii narodnogo obrazovaniâ Urala (s. 104) Perm' [Прокошев, В. В. (ред.). (1976). Из истории народного образования Урала (с. 104) Пермь.].

2. Lihačev, D. S. (red.) (1981). Žitie Sergiâ Radonežskogo. Pamâtniki literatury Drevnej Rusi. XIV - seredina XV vv. (s. 380). Moskva [Лихачев, Д. С. (ред.). (1981). Житие Сергия Радонежского. Памятники литературы Древней Руси. XIV-середина XV вв. (с. 380). Москва.].

3. Dneprov, È. D. (red.). (1985). Očerkiistorii školy i pedagogičeskoj mysli narodov SSSR s drevnejših vremen do konca XVII v. (s. 480). Moskva [Днепров, Э. Д. (ред.). (1985). Очерки истории школь и педагогической мысли народов СССР с древнейших времен до кониа XVII в. (с. 480). Москва].

4. Prokof'ev, I. N. (red.). (1980). Žitie sv. Stefana, episkopa permskogo, napisannoe Epifaniem Premudrym. Drevnââ russkâ̂ literatura (s. 154-160). Moskva [Прокофьев, И. Н. (ред.). (1980). Житие св. Стефана, епископа пермского, написанное Епифанием Премудрым. Древняя русская литература (с. 154-160). Москва].

5. [Klibanov, A. I. (1971). K harakteristike mirovozzreniâ Andreâ Rubleva. Andrej Rublev i ego èpoha (c. 28-87). Moskva [Клибанов, А. И. (1971). К характеристике мировоззрения Андрея Рублева. Андрей Рублев и его эпоха (с. 2887). Москва].

6. Âblokov, I. N. (red.). (2002). Istoriâ religij: učebnik dlâ vuzov: $v 2$ t. (t. 1, s. 463, t. 2, s. 639). Moskva [Яблоков, И. Н. (ред.). (2002). История религий: учебник для вузов: в $2 \mathrm{~m}$. (т. 1, с. 463, т. 2, с. 639). Москва].

7. Savvaitov, P. I. (1873). O zyrânskih derevânnyh kalendarâh i permskoj azbuke. (s. 76). Moskva [Савваитов, П. И. (1873). О зырянских деревянных календарях и пермской азбуке. (с. 76). Москва].

8. Lytkin, V. I. (1952). Drevnepermskij âzyk. (s. 180). Moskva [Лыткин, В. И. (1952). Древнепермский язык. (с. 180). Москва].

9. Permskijsbornik. Knižka pervaâ. (1869). (s.180). Moskva [Пермский сборник. Книжка первая. (1869). (с.180). Москва].

10. Šumilov, E. F. (1996). Hristianstvo v Udmurtii. Civilizacionnye processy i hristianskoe iskusstvo. (s. 176) Iževsk [Шyмилов, Е. Ф. (1996). Христианство в Удмуртии. Цивилизачионные прочессы и христианское искусство. (с. 176) Ижевск.].

11. Epifanij.(1862). Slovo o žitii i učenii sv.Stefana, byvšego v Permi episkopom. Pamâtniki starinnoj russkoj literatury. Vypusk IV. (s. 166). Sankt-Peterburg [Епифаний. (1862). Слово о житии и учении св. Стефана, бывшего в Перми епископом. Памятники старинной русской литератуpы. Выпуск IV. (с. 166). Санкт-Петербург.].

12. Fedotov, G. P. (1990). Svâtitel' Stefan Permskij.V: D. S. Lihačev, A. V. Men' (red.), Svâtye Drevnej Rusi (gl. 7, c.130139). Moskva [Федотов, Г. П. (1990). Святитель Стефан Пермский. В: Д. С. Лихачев, А. В. Мень (ред.), Святыле Древней Руси (гл. 7, с. 130-139). Москва].

13. Lihačev, D. S. (1962). Kul'tura Rusi vremeni Andreâ Rubleva i Epifaniâ Premudrogo (konec XIV inačalo XV vv.). ( с. 340). Moskva [Лихачев, Д. С. (1962). Культура Руси времени Андрея Рублева и Епифания Премудрого (конеи XIV и начало XV вв.). ( с. 340). Москва]. 
ISSN 1508-7719

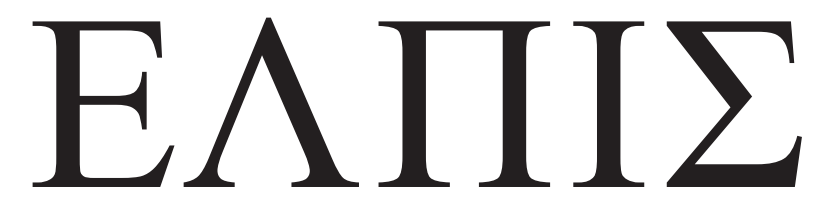

CZASOPISMO TEOLOGICZNE KATEDRY TEOLOGII PRAWOSŁAWNEJ UNIWERSYTETU W BIAŁYMSTOKU

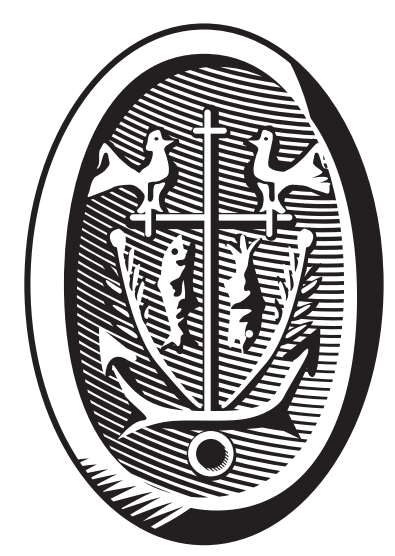

ADRES REDAKCJI

ul. Ludwika Zamenhofa 15, 15-435 Białystok, Polska tel. 85 745-77-80, e-mail: elpis@uwb.edu.pl www.elpis.uwb.edu.pl 